\title{
1 Balancing multiple objectives in organic feed and forage cropping systems
}

3 Meagan E. Schipanski ${ }^{\mathrm{a},}{ }^{\text {, }}$, Mary E. Barbercheck ${ }^{\mathrm{b}}$, Ebony G. Murrell ${ }^{\mathrm{b}}$, Jayson Harper ${ }^{\mathrm{c}}$, Denise M.

4 Finney $^{\mathrm{d}, \mathrm{e}}$, Jason P. Kaye ${ }^{\mathrm{d}}$, David A. Mortensen ${ }^{\mathrm{f}}$, Richard G. Smith ${ }^{\mathrm{h}}$

$5{ }^{a}$ Department of Soil and Crop Sciences, Colorado State University, Fort Collins, CO, USA

$6 \quad{ }^{\mathrm{b}}$ Dept of Entomology, The Pennsylvania State University, University Park, PA, USA

$7 \quad{ }^{c}$ Dept of Agricultural Economics, Sociology, and Education, The Pennsylvania State University,

8 University Park, PA, USA

$9{ }^{\mathrm{d} D e p t}$ of Ecosystem Science and Management, The Pennsylvania State University, University

10 Park, PA, USA

$11{ }^{\mathrm{e}}$ Dept of Biology, Ursinus College, Collegeville, PA, USA

12 f Dept of Plant Science, The Pennsylvania State University, University Park, PA, USA

$13{ }^{\mathrm{h}}$ Dept of Natural Resources and the Environment, University of New Hampshire, Durham, NH,

14 USA

15

$16 *$ Corresponding author:

17 Meagan Schipanski

18 Department of Soil and Crop Sciences

19 Colorado State University

201170 Campus Delivery

21 Fort Collins, CO 80523-1170

22 Email: meagan.schipanski@colostate.edu

23 Phone: 001-970-491-1320 


\section{Abstract}

25 Balancing weed suppression, beneficial insect conservation, soil quality and profitability is

26 challenging in organic cropping systems due to reliance on soil disturbance for weed control. We

27 hypothesized that the benefits of tillage can be retained while mitigating adverse impacts on soil

28 quality by alternating tillage with practices that can build soil organic matter. We conducted a

29 four-year experiment in central Pennsylvania, USA, to compare four organic feed and forage

30 cropping systems, each differing in tillage, manure management, and cropping strategies. Each

31 system was designed to address baseline soil quality and weed pressure conditions arising from

32 practices implemented during the previous three-year transition period. To assess cumulative

33 system effects, we established a soybean (Glycine max) uniformity trial across all systems in

34 year four. Systems that were in perennial forage for 2 years outperformed annual crop-based

35 systems in weed control and beneficial insect conservation, while maintaining overall

36 profitability over the four-year study period. Soybean yields during the uniformity trial were

37 more than $30 \%$ greater in systems that had included perennial forages than in systems with only

38 annual crops. Labile soil carbon pools, an indicator of soil quality, were maintained over time in

39 all systems. Our results indicate that soil quality, weed management, beneficial insect

40 conservation, and profitability can be maintained in organic systems when periodic tillage is

41 coupled with perennial forage crops in rotation.

43 Keywords: cropping systems; multifunctionality; soil quality; perennial crops; weed

44 management; tillage; arthropod natural enemies 
48 Organic management systems have the potential to improve multiple ecosystem services over

49 conventional management systems due to reduced reliance on external inputs and increased

50 reliance on biological processes (Cavigelli et al., 2013). However, balancing pest management,

51 soil quality and profitability can be challenging because tillage is often used for weed and pest

52 management, incorporation of animal and green manures, and preparation of seedbeds. Soil

53 disturbance via tillage can also negatively impact key processes that are the foundation of

54 effective organic management. For example, organic production relies on soil-based processes to

55 support pest and disease management (Bond and Grundy, 2001; van Bruggen and

56 Termorshuizen, 2003), nutrient cycling (Drinkwater and Snapp, 2007), and reduce environmental

57 impacts (Tuomisto et al., 2012). Research is necessary to balance the trade-offs between the

58 benefits and disservices of soil tillage to optimize production, profitability and the ecological

59 processes that support organic production.

61 Over the past decade, there has been growing interest in reduced-till organic management

62 systems (Mirsky et al., 2012; Légère et al., 2013). The development of cover crop termination

63 techniques using a roller-crimper has improved the viability of no-till planting organic crops;

64 however, many organic systems still include inversion tillage within a multi-year rotation

65 (Mirsky et al., 2012). We lack an understanding of the frequency of tillage required to maintain

66 weed control, particularly of perennial weeds, in organic systems. In addition, we lack an

67 understanding of how tillage frequency impacts soil organic matter and beneficial arthropods

68 under different crop rotations and levels of manure input. 
70 Understanding the role that tillage frequency and intensity play in soil quality is an area of

71 interest that extends beyond organic management systems. For example, the increase in

72 herbicide-resistant weeds is leading some no-till producers to return to periodic tillage as a

73 management tool (Price et al., 2011). Periodic tillage may have short-term negative impacts on

74 labile carbon and microbial pools that do not persist beyond a few years (Franzluebbers et al.,

75 1999), but longer-term modeling studies suggest that the effects of periodic tillage can

76 accumulate to negatively affect total soil carbon over time with reduced impacts found for

77 shallow cultivation and non-inversion tillage (Conant et al., 2007). Similarly, a recent meta-

78 analysis indicates that reducing the intensity of tillage in organic systems can improve soil C

79 stocks (Cooper et al., 2016).

80

81 In addition to tillage frequency, crop rotations can also exert a strong influence on weed density,

82 beneficial arthropods, and soil quality. For example, Cardina et al. (2009) found that more

83 diverse, corn-oat-hay rotations had lower weed density compared with continuous corn under no-

84 till management. While less-disturbed cropping systems often have greater insect predator

85 populations, beneficial insect species also respond to previous cash or winter cover crops

86 (Holland and Luff, 2000; Thorbeck and Bilde, 2004; Lundgren and Fergen 2010). Integrating

87 perennial crops, which typically have larger root systems than annuals, into rotations can also

88 contribute to soil quality improvements in addition to reducing tillage frequency (Zan et al.,

89 2001).

90 
91 Organic cropping systems managed with tillage can also maintain or build local soil organic

92 matter, a central component of soil quality, through additions of carbon-rich manure or composts

93 as well as increased use of cover crops (Teasdale et al., 2007). Increasing carbon inputs can

94 offset the stimulatory effect of tillage on soil organic matter decomposition. Therefore,

95 balancing soil quality, beneficial arthropod conservation, and weed control may be achieved

96 through a reduction of tillage frequency and intensity coupled with diversified crop rotations and

97 the use of organic soil amendments.

99 Cropping systems experiments are an important tool for understanding how management

100 strategies influence overall system performance over time. For example, long-term cropping

101 systems studies have highlighted the relative effects of conventional, organic, no-till, reduced

102 input, and conservation tillage systems on a broad suite of agroecosystem functions (Mäder et

103 al., 2002; Syswerda and Robertson, 2014). Within organic management systems, cropping

104 systems studies have allowed us to understand the relative effect of input strategies and crop

105 rotations on yield and profitability (Teasdale et al., 2007; Caldwell et al., 2014) and to identify

106 key drivers of critical ecosystem processes (Finney et al., 2015).

108 One of the challenges with systems experiments is how to allow them to evolve over time using

109 adaptive management strategies. Implementing changes in long-term systems experiments can

110 make it difficult to interpret whether changes are an effect of the newly imposed management

111 system or the previous management legacy. We implemented a novel approach of layering a new

112 experiment across a previous cropping systems experiment that intentionally utilized the soil

113 quality and weed community legacies of the previous experiment. The previous study focused on 
114 identifying successful cover crop and tillage strategies during the 3-year transition phase from

115 conventional to organic management of feed and forage crops in central Pennsylvania. We found

116 that reduced tillage intensity had a positive effect on soil quality indicators, but a negative effect

117 on weed management and crop yields (Jabbour and Barbercheck, 2009; Lewis et al., 2011; Smith

118 et al., 2011; Schipanski et al., 2014). In particular, the switch from moldboard plow to chisel

119 plow contributed to an increased density of a problematic perennial weed (Cirsium arvense,

120 Canada thistle). The second 4-year study period, which we analyze in this paper, was designed to

121 assess the potential of different cropping systems to reduce or maintain initial C. arvense

122 densities while also maintaining or improving soil quality and beneficial arthropod populations.

123 We compared four organic feed and forage cropping systems that differed in tillage frequency

124 and patterns of annual and perennial crops in rotation. We predicted that adverse effects of tillage

125 on soil quality could be mitigated by alternating soil disturbance for weed control with activities

126 that increase soil carbon and beneficial arthropod habitat while maintaining profitability. To

127 evaluate the integrated effect of the different cropping systems, we conducted a one-year

128 uniformity trial at the end of the experiment.

129

130 2. Methods

\subsection{Experimental site and design}

132 The field experiment was conducted at the Russell E. Larson Agricultural Research Center near

133 Rock Springs, PA ( $40^{\circ} 43^{\prime} \mathrm{N}, 77^{\circ} 55^{\prime} \mathrm{W}, 350 \mathrm{~m}$ elevation). The climate of central PA is

134 continental with $975 \mathrm{~mm}$ mean annual precipitation and mean monthly temperatures ranging

135 from $3^{\circ} \mathrm{C}$ (January) to $21.6^{\circ} \mathrm{C}$ (July). The dominant soil type at this location is Hagerstown silt 
136 loam (Fine, mixed, semiactive, mesic, Typic Hapludalf). Soil texture was predominantly clay

137 loam with spatial variability in silt (range of 45.5-54.7\%) and sand (14.0-26.4\%).

139 The field experiment was established twice, in the fall of 2007 for the first start (Start 1) and 140 again in fall 2008 for the second start (Start 2). Four rotation systems were established in a 141 randomized complete block design with four replications. Each plot was 0.067 ha. The rationale

142 supporting the approach to management in each system was based on the population densities of

143 Canada thistle (Cirsium arvense, a perennial weed) that were present at the end of the previous

144 experiment evaluating the effects of tillage intensity on weed dynamics and soil quality

145 (Schipanski et al., 2014). Systems 1 and 3 were designed to focus on reducing C. arvense

146 populations and systems 2 and 4 were designed to maintain low C. arvense populations (Table

147 1). Specifically, system 1 was designed to reduce perennial weed pressure through high initial

148 disturbance frequency with short-season cover crops in year one followed by two years of

149 perennial forage to build soil quality. System 2 was designed to suppress perennial weeds

150 through high biomass production of annual forage in year one with reduced disturbance followed

151 by two years of perennial forage to build soil quality. System 3 was designed to reduce perennial

152 weeds through intensive soil disturbance during a tilled summer fallow in year one followed by

153 annual crops planted with and without tillage in years two and three, respectively. System 4 was

154 designed to suppress perennial weeds and build soil quality through low frequency soil

155 disturbance and the maintenance of constant biomass cover in years one and two, followed by

156 tillage and annual cropping year three. 
158 The four experimental systems varied in terms of crop rotations, tillage frequency, and manure

159 applications (Table 1). All systems were moldboard plowed and planted with a cereal rye (Secale

160 cereale) and hairy vetch (Vicia villosa) cover crop in August of experimental year 0 (2007 for

161 Start 1 and 2008 for Start 2). We define 'conventional tillage' as inversion tillage with a

162 moldboard plow. System 1 employed a sequence of conventionally tilled summer cover crops in

163 year one to reduce populations of $C$. arvense followed by two years of a perennial cash crop,

164 alfalfa (Medicago sativa). System 2 employed a single cash crop established with conventional

165 tillage in the summer of year one (sudangrass, Sorghum bicolor ssp. drummondii) followed by a

166 fall fallow period to reduce annual weeds. An alfalfa and orchardgrass (Dactylis glomerata)

167 biculture was established in year two and maintained for two years. In System 3, the initial cereal

168 rye/hairy vetch cover crop was allowed to grow through July of year one and was followed by a

169 tilled fallow to reduce $C$. arvense populations. The tilled fallow included shallow, non-inversion

170 tillage with an S-tine cultivator 3 times over a 2-month period. A small grain cash crop (cereal

171 rye) was established in fall year one and harvested in July year two, followed by a summer

172 planted triticale (Triticale hexaploide) and hairy vetch cover crop; both crops were managed with

173 conventional tillage. In year three, corn (Zea mays) was planted without tillage. System 4 sought

174 to re-build soil organic matter through successive cover crops established without tillage prior to

175 planting conventionally tilled corn in year 3. Thus, each system employed distinct approaches to

176 managing weeds in ways that might deplete organic matter (e.g. tillage and fallow periods)

177 alternated with practices that should rebuild organic matter (cover crops, perennial crops, no-till

178 cash crops, manure inputs). While this diverse and realistic array of practices is a strength of the

179 project, it also represented a challenge, since all treatments differed in multiple ways. Thus, to

180 assess cumulative system effects and because yield comparisons were difficult to make across 
181 the diversity of crops in each rotation year, we established a uniformity trial across all systems in

182 year four. All plots were plowed and disked and planted to soybeans in June of year four.

183 Soybean (Glycine max) was selected because of its biological nitrogen fixation potential to

184 equalize differences in background nitrogen levels. Within each main plot during the uniformity

185 trial, we established subplots $(3 \mathrm{~m} \times 3 \mathrm{~m})$ of a non-nodulating soybean variety (seed provided by

186 J. Orf, University of Minnesota) to assess system effects on soil nitrogen availability.

188 All systems used tillage, but tillage frequency varied across treatments. The shading in Table 1

189 distinguishes between crops established without tillage or with conventional tillage.

190 Conventional tillage is defined as inversion tillage with a moldboard plow (Table 1). In

191 conventionally tilled cash crops (corn and soybeans), we used tillage and inter-row cultivation to

192 manage in-season weeds. During periods managed without tillage (Table 1), no plowing

193 operations were performed prior to crop establishment and cover crops were terminated by

194 mowing or rolling. We applied manure in the spring prior to sorghum sudangrass (System 2, year

195 one) and corn (Systems 3 and 4, year three) production. We determined manure application rates

196 following standard nutrient management practices used by farmers in the region as outlined in

197 the Penn State Agronomy Guide (Table 1, Beegle, 2008). For a detailed summary of manure N

198 inputs, see Finney et al. (2015).

$200 \quad 2.2$ Data collection

201 2.2.1 Weeds

202 Weed density and biomass were sampled annually within each plot in September to capture data

203 at peak biomass and prior to senescence. Within each plot all weeds were counted, identified, 
204 and clipped within five replicate $0.25 \mathrm{~m}^{2}$ quadrats. For rhizomatous weeds, such as $C$. arvense,

205 each stem was counted as one individual. Biomass samples were dried at $55^{\circ} \mathrm{C}$ and weighed.

207 2.2.2 Yields

208 Yields are difficult to compare across management systems during the first three years of the

209 experiment due to the different rotations (Table 2). Therefore, we focused yield analysis on the

210 uniformity trial conducted at the end of the experiment in year four. Soybean seed yields during

211 the uniformity trial were sampled from the center five rows of each plot (0.021 ha) using a

212 combine with a weighing system. A subsample was collected to correct yields for moisture

213 content.

214

215 Aboveground biomass of the nodulating and non-nodulating soybeans was measured by clipping

216 all aboveground tissues from $1.5-\mathrm{m}^{2}$ within the center of $3 \mathrm{~m} \times 3 \mathrm{~m}$ subplots prior to leaf

217 senescence in September of each year. Biomass samples were dried, ground, and analyzed for

218 total $\mathrm{C}$ and $\mathrm{N}$ using an elemental analyzer (EA1110 Elemental Analyzer, CE Instruments).

$220 \quad$ 2.2.3 Soil quality indicators

221 Soils were sampled each fall (September/October). At each sampling, three composite soil 222 samples were collected from random locations within each plot. Each sample comprised 15

223 individual soil cores (2.5-cm diameter x $15-\mathrm{cm}$ depth).

225 Permanganate oxidizable C (POXC) was measured as an indicator of soil labile $\mathrm{C}$ following

226 protocols developed by Weil et al. (2003). For each sample, we combined $5 \mathrm{~g}$ of air-dried, 
227 sieved $(2 \mathrm{~mm})$ soil with $20 \mathrm{ml}$ of $0.02 \mathrm{M}$ permanganate solution in a polycarbonate tube. The

228 permanganate solution contained $0.2 \mathrm{M}$ potassium permanganate $\left(\mathrm{KMnO}_{4}\right)$ and $1 \mathrm{M}$ calcium

229 chloride $\left(\mathrm{CaCl}_{2}\right)$, and was adjusted to a $\mathrm{pH}>7.2$ using sodium hydroxide $(\mathrm{NaOH})$. Samples were

230 shaken for 2 minutes and then allowed to settle for 10 minutes. Next, $0.2 \mathrm{ml}$ of supernatant from

231 this slurry was added to $9.8 \mathrm{ml}$ of deionized water, and this solution was briefly shaken by hand.

232 The consequent reduction of permanganate was estimated with a spectrophotometer at $550 \mathrm{~nm}$.

233 We assumed 9 mol of organic $\mathrm{C}$ were oxidized for every 1 mole of permanganate reduced.

235 Soil bulk density was measured in fall of year 0 and spring and fall of year four by collecting soil

236 cores at three depths (i.e., $0-10 \mathrm{~cm}, 10-20 \mathrm{~cm}$, and $20-30 \mathrm{~cm}$ ) in two random locations per plot.

237 A hammer-driven core sampler was used to obtain intact soil cores at each depth using aluminum

238 rings (7.62-cm length $\times 7.62-\mathrm{cm}$ inner diameter). Soil samples were dried and weighed and

239 sieved to $2 \mathrm{~mm}$ for coarse rock fragment correction (Blake and Hartge, 1986). Soil carbon data

240 were adjusted from concentration $\left(\mathrm{mg} / \mathrm{kg}\right.$ soil) to content $\left(\mathrm{g} / \mathrm{m}^{2}\right)$ using a weighted average of the

$2410-10 \mathrm{~cm}$ and $10-20 \mathrm{~cm}$ bulk density measurements.

242

243 2.2.4 Predatory arthropods

244 We focused on ground-dwelling predatory arthropods as an indicator of rotation impacts on

245 beneficial insects and as an indicator of biological pest management potential (Cardinale et al.,

246 2003; Symondson et al., 2002). Pitfall traps were used to assess activity-density of five major

247 arthropod groups: Spiders (Order Araneae), harvestmen (Order Opiliones), ground and tiger

248 beetles (Order Coleoptera, Family Carabidae), rove beetles (Order Coleoptera, Family

249 Staphylinidae), and centipedes (Order Chilopoda). Of the 17 orders or families that were 
250 collected from our pitfall traps, these five taxa represented $31 \%$ by abundance and $42 \%$ by taxon

251 richness of all arthropods captured in the traps. Additionally, these taxa consist primarily of

252 generalist predators (Lang 2003) whose activity-densities can be assessed using pitfall traps

253 (Woodcock, 2005; Prasifka et al., 2007). Three traps were placed in each plot on the following

254 dates: 11/2/2006 (Start 1 only), 11/1/2007 (Start 2 only), 8/11/2008 (Start 1 only), 9/3/2009,

$2558 / 9 / 2010,9 / 19 / 2011$, and 8/27/2012 (Start 2 only). Each trap consisted of a plastic deli container

$25611.4 \mathrm{~cm}$ in diameter and $12.9 \mathrm{~cm}$ deep, containing a small sample cup in the bottom $(8.7 \mathrm{~cm}$

257 diameter $\mathrm{x} 6 \mathrm{~cm}$ depth) with a plastic funnel placed on top to prevent accidental trapping of

258 larger organisms. Each trap was buried with the container lip flush with the soil surface, and its

259 sample cup was filled with $40 \mathrm{~mL}$ ethylene glycol. Traps were collected after $72 \mathrm{~h}$. Trapped

260 arthropods were preserved in scintillation vials with $80 \%$ ethanol plus $1 \mathrm{~mL}$ glycerol for storage,

261 and later identified to order or family in the laboratory. Pitfall traps were removed from the field

262 after each sampling event.

263

$264 \quad 2.2 .5$ Economic analysis

265 Enterprise budgets were constructed based on actual field activities and costs of inputs for the

266 four systems and two starts over the four years of the study, plus the initial cover crop

267 establishment phase. Machinery costs were based on the type of implements used in the

268 experiments adjusted to machinery sizes and tractors that are typically used on Pennsylvania

269 dairy farms. The budgets were constructed to estimate both variable costs (those that vary with

270 the level and intensity of production like labor, fuel, soil amendments, seed, repairs, and harvest)

271 and fixed costs (those that relate to the ownership of machinery like depreciation, interest, and

272 insurance). No charges for management or land were included in the budgets. 
274 Because the overall profitability of these systems depended heavily on the sequencing of

275 operations in previous years, it was necessary to evaluate the cash flow streams generated by

276 each system over time. Annual cash flow estimates for the systems were calculated based on

277 three price scenarios (low, medium, and high) and actual yields obtained in the experiments. The

278 net present value of the cash flow for each production system was then calculated for the three

279 price scenarios. Net present value analysis compares the value of a dollar today to the value of a

280 dollar in the future, taking inflation and decision maker time preferences into account by use of a

281 discount rate. The net present value expresses a projected stream of future cash flows as a single

282 value and allows for the direct comparison of alternatives. A production system with a cash flow

283 stream that generates a positive net present value would merit consideration for adoption. A $6 \%$

284 discount rate was used in the evaluation. This is an acceptable rate to use given current

285 inflationary expectations and the anticipation of generating a moderate level of return on capital.

$287 \quad 2.3$ Data analysis

288 We conducted all soil and weed analyses using mixed models in JMP v.11 (SAS, Cary, NC).

289 Start and block were included as nested random factors in mixed models comparing management

290 systems. Weed data were log transformed to meet normal distribution model assumptions. For

291 analysis of temporal trends, rotation year was included as a fixed factor. Total activity-densities

292 of the five arthropod taxa combined were analyzed by system for each year using mixed models

293 in SAS (PROC GLIMMIX, SAS 9.4) with a log-normal distribution. Significant differences

294 among systems were assessed using pairwise comparisons with a Tukey adjustment. 


\section{Results}

297 Results from the soybean uniformity trial at the end of the 4-year systems experiment indicate

298 that the perennial-based Systems 1 and 2 outperformed the annual-based Systems 3 and 4 in

299 annual weed control, while all systems maintained perennial weed control. Density of the target

300 perennial weed, $C$. arvense, decreased or was maintained at low levels across all systems.

301 Cirsium arvense density in year three was significantly reduced from year 0 in Systems 1 and 3,

302 which had higher initial $C$. arvense density due to reduced tillage intensity during the previous

303 experiment (Figure 1). The system with the lowest tillage frequency during this experiment,

304 System 4, had higher $C$. arvense density in year three; however, density was not significantly

305 different from year 0 or from the other three systems in year three (Figure 1). Perennial weed

306 biomass was low across all systems in year four when the soybean uniformity trial was managed

307 with inversion tillage prior to planting and subsequent cultivation events (Figure 2). C. arvense

308 density was less than 0.5 plants $\mathrm{m}^{-2}$ across all systems during the uniformity trial.

310 Annual weeds, in contrast, differed across systems during the uniformity trial. Annual weed

311 biomass was four times greater in Systems 3 and 4 following corn than in Systems 1 and 2

312 following alfalfa and alfalfa/orchardgrass, respectively. Dominant annual weed species included

313 Amaranthus spp. and Chenopodium album that represented $41 \%$ and $37 \%$, respectively, of the

314 total annual weed biomass across all systems in year four (community data not shown).

316 Weed biomass was inversely correlated with yields in the soybean uniformity trial $(\mathrm{r}=-0.81$,

$317 P<0.0001)$. Average soybean yields in the uniformity trial were more than $30 \%$ greater in

318 Systems 1 and 2, than in Systems 3 and 4 (Figure 3). 
320 Soil quality indicators generally did not differ across management systems with the exception of

321 labile soil C. Permanganate oxidizable C (POXC) was higher in System 3 than System 1 during

322 the uniformity trial in year four (Figure 4). Bulk density, another soil quality indicator, did not

323 differ across management systems at the start or end of the experiment (Supplementary Table 1).

325 Nitrogen uptake by non-nodulating soybean was greater following alfalfa-orchardgrass in

326 System 2 than following corn receiving manure in Systems 3 and 4 (Figure 5). For both systems

327 following alfalfa in mixture or monoculture non-nodulating soybeans took up $150 \mathrm{~kg} \mathrm{~N} / \mathrm{ha}$ in

328 aboveground biomass, while in Systems 3 and 4 uptake was less than $100 \mathrm{~kg} \mathrm{~N} / \mathrm{ha}$.

330 Predatory arthropod abundances did not differ among systems during the transition year or the

331 first year of the study (Figure 6). Beginning at the fall sampling in year two, predators had

332 significantly higher activity-densities in both perennially-based systems (Systems 1 and 2) than

333 in the annual-based systems (Systems 3 and 4, Figure 6). System 1 retained higher arthropod

334 abundances in year three than Systems 3 and 4, when both annual systems were planted to corn.

335 During the soybean uniformity year, predator activity-densities were reduced across all systems,

336 but remained significantly higher in the perennial-based systems than in System 4 (Figure 6).

338 System 2, a system with annual and perennial forages, was more profitable than the other

339 systems. Averaged across Start 1 and 2, System 2 performed well regardless of the price

340 scenario. All systems had a positive net present value (NPV) when averaged across price

341 scenarios, a single measure of the overall value of the individual year cash flows over the full 4- 
342 year rotation (Figure 7). System 2 had positive cash flows for three years and a higher NPV. The

343 NPV of systems 1, 3 and 4, were similar though annual cash flows varied across the systems

344 (Figure 7). When separated by Start, the lower yields in Start 2 (Table 2) contributed to negative

345 NPV for all systems except at the high price scenario. System 2 had a greater NPV than the other

346 systems across both starts.

348 4. Discussion

349 Our results provide insights into the frequency of soil disturbance required to reduce perennial

350 weeds, such as $C$. arvense, in organic cropping systems while balancing other management

351 objectives. The integration of perennial legume-based forages into annual feed and forage

352 rotations provided the broadest suite of functions, including reducing weed pressure, increasing

353 soil nitrogen supply, supporting beneficial soil arthropods, and maintaining soil quality and net

354 profitability. Soil quality was also maintained in annual-based crop rotations that received

355 periodic manure additions.

356

357 Perennial weed density was influenced by the frequency of soil disturbance over the 4 year

358 rotation. System 3, which included tillage in 3 of the 4 years, reduced $C$. arvense density from

359 initial density levels (Figure 1). In contrast, System 4, which had the least frequent soil

360 disturbance with tillage only in 1 of 4 years, showed a shift toward increasing $C$. arvense density

361 by year three, but the difference was not significant. While this study focused primarily on the

362 frequency of tillage, our previous study found similar results when looking at reducing tillage

363 intensity (Smith et al., 2011; Schipanski et al., 2014). Long-term no-till and reduced tillage

364 systems often result in increasing perennial weed populations (Blackshaw et al., 1994; Peigné et 
365 al., 2007), but little research has been conducted to understand how periodic tillage may

366 influence perennial weeds. Our results suggest that inversion tillage in one out of every three

367 years may be sufficient to maintain perennial weed control in organic systems in conjunction

368 with other standard practices such as good crop management that maintains plant competition.

370 Perennial crop competition paired with periodic mowing may provide an alternative method to

371 soil disturbance for control of annual and perennial weeds. The perennial forages were more

372 effective than annual crops at suppressing annual weeds. Even with inversion tillage and

373 cultivation events, annual weed pressure was higher following corn than following perennial

374 forages (Figure 2). Perennial forages reduce both annual and perennial weed pressure in the

375 following crop and can shift the composition of weed communities over time (Entz et al., 2002).

376 In particular, increasing phenological diversity in rotations through the inclusion of both annual

377 and perennial crops can reduce annual weed pressure in organic cropping systems (Teasdale $e t$

378 al., 2004). Perennial forages may also reduce the weed seedbank due to increased weed seed

379 predation (Meiss et al., 2010).

381 Perennial legume forages also supported increased $\mathrm{N}$ uptake by the following annual crop. The $\mathrm{N}$

382 uptake by the non-nodulating soybeans was similar to estimates of the $\mathrm{N}$ contributions of

383 perennial alfalfa and alfalfa-mixtures that are commonly around $150-200 \mathrm{~kg} \mathrm{~N} / \mathrm{ha}$ from

384 biological $\mathrm{N}$ fixation (Russelle and Birr, 2004). Approximately 50-60\% of this $\mathrm{N}$ becomes

385 available in the first year, while the remainder is released more slowly over multiple years (Yost

386 et al., 2013). This $\mathrm{N}$ input represents an important economic benefit for organic producers who

387 do not have an inexpensive source of manure. However, the large pulse of $\mathrm{N}$ following perennial 
388 legume termination can also result in potential $\mathrm{N}$ leaching and $\mathrm{N}_{2} \mathrm{O}$ emissions (Jensen et al.,

389 2011; Finney et al., 2015). The alfalfa-orchardgrass mixture provided a similar amount of $\mathrm{N}$ as

390 the pure alfalfa stand. Mixtures tend to have improved N synchrony with crop demand due to the

391 higher C:N of the residue (Wagger et al., 1998).

392

393 Despite the short-term benefits of perennial forage increasing readily mineralizable $\mathrm{N}$, the

394 systems with perennial forages did not result in higher labile soil organic matter pools. In

395 particular, System 2 that was designed to build soil quality through high biomass annual and

396 perennial forages, had labile soil C levels that were less than or equivalent to more frequently

397 tilled annual systems such as System 3 (Figure 4). Perennial plants tend to increase soil carbon

398 stocks at a faster rate than annuals, but the rate of soil carbon accumulation varies considerably

399 with region, species, and management context (Guo and Gifford, 2002; Machmuller et al., 2015).

400 The time scale of our study may have limited our ability to detect the impact of perennial root

401 systems on soil C pools.

402

403 Labile soil $\mathrm{C}$ and $\mathrm{N}$ pools were influenced by an interactive effect of manure additions and

404 tillage frequency. Tillage is known to reduce soil $\mathrm{C}$ pools, while manure additions can increase

405 soil organic $\mathrm{C}$ pools under both tilled and no-till systems (Mikha and Rice, 2004). The higher

406 POXC pools in System 3 relative to System 1 at the end of the experiment were likely due to

407 higher starting levels as a result of reduced tillage during the previous experiment and the

408 external organic matter inputs via manure applications. Annual POXC levels increased following

409 each manure addition (Figure 4; see System 2, year 1; Systems 3 and 4, year 3). The increase in

410 SOM in many long-term organic systems trials are often supported both by increased plant C 
411 inputs and by applications of manures or composts that effectively offset $\mathrm{C}$ losses due to tillage

412 events (e.g., Teasdale et al., 2007). The source of these $\mathrm{C}$ inputs can influence the net $\mathrm{C}$ balance

413 of a farming operation. While the source may be from within the same farm in integrated crop-

414 livestock systems, manures and composts applied to organic farms are often an imported nutrient

415 source subsidized by nearby conventional operations.

417 The activity-densities of predatory arthropods in the perennially-based systems in years two and

418 three is not surprising, given that alfalfa fields are known for supporting highly diverse predator

419 communities (Grez et al., 2014). Less-disturbed systems typically have greater predator

420 populations (House and Stinner, 1983), but individual species can respond idiosyncratically to

421 tillage and previous cash or winter cover crops (Holland and Luff, 2000, Lundgren and Fergen,

422 2010). Both tillage and previous cropping history can influence arthropod communities. The

423 higher activity-densities in our perennial systems, relative to the annual systems, were retained

424 even during the soybean uniformity trial. In a previous study, predator abundance was greater in

425 corn following an autumn-planted, spring-killed grass cover crop, Elymus trachycaulus,

426 compared to corn without a preceding cover crop (Lundgren and Fergen, 2010). Activity-

427 densities of the carabid beetle, Harpalus rufipes DeGeer, were greater in conventionally-tilled

428 corn following a pea/oat-cereal rye/hairy vetch cover crop system compared to treatments

429 without a preceding cover crop (Shearin et al., 2008). The activity-densities of H. rufipes were

430 greatest in systems representing a medium level of disturbance among the various systems

431 (Shearin et al., 2008), thus suggesting that for at least some predators, some level of disturbance

432 may be beneficial for species diversity.

433 
434 Our results suggest that rotations with a mixture of annual and perennial crops have the best

435 potential for maintaining positive cash flows over time across variable weather years. System 2

436 had the highest average NPV over the full four-year experiment due to a combination of factors.

437 The alfalfa/orchardgrass yields maintained positive cash flows in years two and three and then

438 the weed suppressive effect of the perennial forage, greater $\mathrm{N}$ supply, and greater predatory

439 arthropod density likely all contributed to higher soybean yields in year four. The challenge for

440 some producers in certain parts of the U.S. in integrating more perennial crops into rotations is

441 the need for a relatively local market or the integration of on-farm crop-livestock systems.

442

\section{5. Conclusions}

444 Our goal was to identify key principles for managing organic cropping systems for multiple 445 agronomic and agri-environmental objectives. Our results indicate that multiple management

446 tools are required to manage for multiple outcomes. Reducing tillage frequency to once every

447 two to three years, coupled with maintaining crop competition, successfully maintained perennial

448 weed control without reducing soil quality. The integration of perennial forages has the potential

449 to provide better annual weed control, conservation of arthropod natural enemies, and

450 profitability than annually tilled systems. External manure applications can offset tillage impacts

451 on labile soil C and maintain or improve soil quality. In organic feed and forage systems, overall

452 system profitability is largely dependent on reducing input costs, maintaining annual cash flows,

453 and effective weed and beneficial insect management. While organic agriculture is often

454 criticized for negative environmental impacts of tillage on soils, here we show that reducing

455 tillage by rotating tillage practices and soil building events over time is a viable strategy to 
maintain low weed populations without diminishing soil labile C, profitability, and beneficial

457 soil arthropods.

\section{Acknowledgements}

460 We would like to thank S. Eckert, D. Sandy, S. Smiles, S. Harkcom, and C. Mullen for their

461 assistance with field management and data collection. We would like to thank our project

462 advisory board for their helpful input, including J. Moyer, L. Zuck, B. Snyder, R. Robertson, T.

463 DuPont, L. Garling, P. Yoder, A. Ziegler, K. Yoder, and W. Esbenshade. The manuscript was

464 improved by helpful input from anonymous reviewers. This project was funded by USDA

465 CSREES-ICGP Risk Avoidance and Mitigation Program (grant no. 2007-03085 to M.E.

466 Barbercheck).

\section{References}

469 Beegle D. 2008. Section 2: Soil fertility management. Pennsylvania State Agronomy Guide 2007-2008. The Pennsylvania State University, University Park, PA. effects on weed populations on the semi-arid Canadian prairies. Weed Technology, 231237.

Blake, G.R., and K.H. Hartge. 1986. Bulk density. p. 363-375. In A. Klute (ed.) Methods of soil analysis. Part 1. 2nd ed. Agronomy Monographs 9. ASA and SSSA, Madison, WI.

Bond, W., Grundy, A.C. 2001. Non-chemical weed management in organic farming systems. Weed Research 41, 383-405.

Caldwell, B., Mohler, C.L., Ketterings, Q.M., DiTommaso, A. 2014. Yields and profitability during and after transition in organic grain cropping systems. Agronomy Journal 106, $871-880$.

Cardina, J., Herms, C.P., Doohan, D.J. 2009. Crop rotation and tillage system effects on weed seedbanks. Weed Science 50, 448-460.

Cardinale, B. J., Harvey, C. T., Gross, K., Ives, A. R. 2003. Biodiversity and biocontrol: emergent impacts of a multi- enemy assemblage on pest suppression and crop yield in an agroecosystem. Ecology Letters 6, 857-865. 
Cavigelli, M.A., Mirsky, S.B., Teasdale, J.R., Spargo, J.T., Doran, J. 2013. Organic grain cropping systems to enhance ecosystem services. Renewable Agriculture and Food Systems 28, 145-159.

Conant, R.T., Easter, M., Paustian, K., Swan, A., Williams, S. 2007. Impacts of periodic tillage on soil C stocks: A synthesis. Soil and Tillage Research 95, 1-10.

Cooper, J., Baranski, M., Stewart, G., et al. 2016. Shallow non-inversion tillage inorganic farming maintains crop yields and increases soil C stocks: a meta-analysis. Agronomy for Sustainable Development 36, 22. doi:10.1007/s13593-016-0354-1

Drinkwater, L.E. and Snapp, S.S. 2007. Nutrients in agroecosystems: rethinking the management paradigm. Advances in Agronomy 92,163-186.

Entz, M.H., Baron, V.S., Carr, P.M., Meyer, D.W., Smith, S. and McCaughey, W.P. 2002. Potential of forages to diversify cropping systems in the Northern Great Plains. Agronomy Journal 94, 240-250.

Finney, D.M., Eckert, S.E. and Kaye, J.P. 2015. Drivers of nitrogen dynamics in ecologically based agriculture revealed by long-term, high-frequency field measurements. Ecological Applications 25(8), 2210-2227.

Franzluebbers, A., Langdale, G., Schomberg, H. 1999. Soil carbon, nitrogen, and aggregation in response to type and frequency of tillage. Soil Science Society of America Journal 63, 349-355.

Grez, A. A., Zaviezo, T., and Gardiner, M. M. 2014. Local predator composition and landscape affects biological control of aphids in alfalfa fields. Biological Control, 76:1-9.

Guo, L.B., Gifford, R. 2002. Soil carbon stocks and land use change: a meta analysis. Global Change Biology 8, 345-360.

Holland, J. M., and M. L. Luff. 2000. The effects of agricultural practices on Carabidae in temperate agroecosystems. Integrated Pest Management Review 5, 105-125.

House, G. J., Stinner, B. R. 1983. Arthropods in no-tillage soybean agroecosystems: community composition and ecosystem interactions. Environmental Management 7, 23-28.

Jabbour, R., Barbercheck, M. 2009. Soil management effects on entomopathogenic fungi during the transition to organic agriculture in a feed grain rotation. Biological Control 51, 435-443.

Jensen, E.S., Peoples, M.B., Boddey, R.M., Gresshoff, P.M., Hauggaard-Nielsen, H., J.R. Alves, B., Morrison, M.J. 2011. Legumes for mitigation of climate change and the provision of feedstock for biofuels and biorefineries. A review. Agronomy for Sustainable Development 32, 329-364.

Lang, A. 2003. Intraguild interference and biocontrol effects of generalist predators in a winter wheat field. Oecologia, 134:144-153.

Légère, A., Shirtliffe, S.J., Vanasse, A., Gulden, R.H. 2013. Extreme grain-based cropping systems: When herbicide-free weed management meets conservation tillage in northern climates. Weed Technology 27, 204-211.

Lewis, D.B., Kaye, J.P., Jabbour, R., Barbercheck, M.E. 2011. Labile carbon and other soil quality indicators in two tillage systems during transition to organic agriculture. Renewable Agriculture and Food Systems 26, 342-353.

Lundgren, J.G. and Fergen, J.K. 2010. The effects of a winter cover crop on Diabrotica virgifera (Coleoptera: Chrysomelidae) populations and beneficial arthropod communities in no-till maize. Environmental entomology 39(6), 816-1828. 
Machmuller, M.B., Kramer, M.G., Cyle, T.K., Hill, N., Hancock, D., Thompson, A. 2015. Emerging land use practices rapidly increase soil organic matter. Nature Communications 6. doi:10.1038/ncomms7995.

Mäder, P., Fliessbach, A., Dubois, D., Gunst, L., Fried, P., Niggli, U. 2002. Soil fertility and biodiversity in organic farming. Science 296, 1694-1697.

Meiss, H., Le Lagadec, L., Munier-Jolain, N., Waldhardt, R., Petit, S. 2010. Weed seed predation increases with vegetation cover in perennial forage crops. Agriculture, Ecosystems \& Environment 138, 10-16.

Mikha, M.M., Rice, C.W. 2004. Tillage and manure effects on soil and aggregate-associated carbon and nitrogen. Soil Science Society of America Journal 68, 809-816.

Mirsky, S.B., Ryan, M.R., Curran, W.S., Teasdale, J.R., Maul, J., Spargo, J.T., Moyer, J., Grantham, A.M., Weber, D., Way, T.R. 2012. Conservation tillage issues: Cover cropbased organic rotational no-till grain production in the mid-Atlantic region, USA. Renewable Agriculture and Food Systems 27, 31-40.

Peigné, J., Ball, B.C., Roger-Estrade, J. and David, C. 2007. Is conservation tillage suitable for organic farming? A review. Soil Use and Management 23(2), 129-144.

Prasifka, J. R., Lopez, M. D., Hellmich, R. L., Lewis, L. C., and Dively, G. P. 2007. Comparison of pitfall traps and litter bags for sampling ground- dwelling arthropods. Journal of Applied Entomology, 131:115-120.

Price, A.J., Balkcom, K., Culpepper, S., Kelton, J., Nichols, R., Schomberg, H. 2011. Glyphosate-resistant Palmer amaranth: a threat to conservation tillage. Journal of Soil and Water Conservation 66, 265-275.

Russelle, M.P., Birr, A.S. 2004. Large-scale assessment of symbiotic dinitrogen fixation by crops. Agronomy Journal 96, 1754-1760.

Schipanski, M.E., Smith, R.G., Gareau, T.L.P., Jabbour, R., Lewis, D.B., Barbercheck, M.E., Mortensen, D.A., Kaye, J.P. 2014. Multivariate relationships influencing crop yields during the transition to organic management. Agriculture, Ecosystems \& Environment 189, 119-126.

Shearin, A.F., Reberg-Horton, S.C., Gallandt, E.R. 2008. Cover crop effects on the activitydensity of the weed seed predator Harpalus rufipes (Coleoptera: Carabidae). Weed Science 56, 442-450.

Smith, R.G., Barbercheck, M.E., Mortensen, D.A., Hyde, J., Hulting, A.G.,2011. Yield and net returns during the transition to organic feed grain production. Agronomy Journal 103, 5159.

Symondson, W. O. C., Sunderland, K. D., Greenstone, M. H. 2002. Can generalist predators be effective biocontrol agents? Annual Review of Entomology 47, 561-594.

Syswerda, S.P., Robertson, G.P. 2014. Ecosystem services along a management gradient in Michigan (USA) cropping systems. Agriculture, Ecosystems \& Environment 189, 28-35.

Teasdale, J.R., Mangum, R.W., Radhakrishnan, J., Cavigelli, M.A. 2004. Weed seedbank dynamics in three organic farming crop rotations. Agronomy Journal 96, 1429-1435.

Teasdale, J.R., Coffman, C.B., Mangum. R.W. 2007. Potential benefits of no-tillage and organic cropping systems for grain production and soil improvement. Agronomy Journal 99, $1297-1305$.

Thorbek, P., Bilde. T. 2004. Reduced numbers of generalist arthropod predators after crop management. Journal of Applied Ecology 41, 526-538. 
Tuomisto, H.L, Hodge, I.D., Riordan, P., Macdonald, D.W. 2012. Does organic farming reduce environmental impacts? - A meta-analysis of European research. Journal of Environmental Management 112, 309-320.

van Bruggen, A. H., Termorskuizen, A. J. 2003. Integrated approaches to root disease management in organic farming systems. Australasian Plant Pathology 32, 141-156.

Wagger, M., Cabrera, M., Ranells, N. 1998. Nitrogen and carbon cycling in relation to cover crop residue quality. Journal of Soil and Water Conservation 53, 214-218.

Weil, R.R., Islam, K.R., Stine, M.A., Gruver, J.B., Samson-Liebig, S.E. 2003. Estimating active carbon for soil quality assessment: A simplified method for laboratory and field use. American Journal of Alternative Agriculture 18, 3-17.

Woodcock, B. A. 2005. Pitfall trapping in ecological studies. In Insect Sampling in Forest Ecosystems [ed. S. Leather], Ch. 3, pp 37-57. Blackwell Science Ltd.: Malden, MA USA.

Yost, M.A., Coulter, J.A., Russelle, M.P. 2013. First-year corn after alfalfa showed no response to fertilizer nitrogen under no-tillage. Agronomy Journal 105, 208-214.

Zan, C.S., Fyles, J.W., Girouard, P., and Samson, R.A. 2001. Carbon sequestration in perennial bioenergy, annual corn and uncultivated systems in southern Quebec. Agriculture, Ecosystems \& Environment 86, 135-144. 
Table 1. The previous and current experiment management strategies for 4 organic feed and forage cropping systems, including the cumulative number of inversion and secondary tillage events and the 4-year cropping sequence for each system initiated in 2007 (Start 1) and 2008 (Start 2) near Rock Springs, PA.

\section{System 1}

\begin{tabular}{cl}
\hline Previous experiment management & Reduced tillage \\
Management strategy & $\begin{array}{l}\text { Perennial crops with } \\
\text { high disturbance } \\
\text { initially to reduce } \\
\text { perennial weed pressure }\end{array}$ \\
\hline Inversion tillage events in Yrs $1-3^{\mathrm{a}}$ & 3
\end{tabular}

\section{System 2}

Full tillage

Perennial and annual forages with reduced disturbance to rebuild soil quality

\section{2}

7
System 3

Reduced tillage

Annual crops with

disturbance, including

high intensity tilled

fallow, to reduce perennial weed pressure 2

8

\section{System 4}

\section{Full tillage}

Annual crops with low disturbance to rebuild soil quality

1

\begin{tabular}{|c|c|c|c|c|c|c|c|}
\hline Year & Start 1 & Start 2 & Season & \multicolumn{4}{|c|}{ Cropping Sequence } \\
\hline 0 & 2007 & 2008 & $\mathrm{Fa}$ & \multirow{2}{*}{ Rye \& hairy vetch } & \multirow{3}{*}{ Rye \& hairy vetch } & \multirow{3}{*}{ Rye \& hairy vetch } & \multirow{3}{*}{ Rye \& hairy vetch } \\
\hline \multirow{4}{*}{1} & \multirow[t]{4}{*}{2008} & \multirow[t]{4}{*}{2009} & $\mathrm{Wi}$ & & & & \\
\hline & & & $\mathrm{Sp}$ & Mustard & & & \\
\hline & & & $\mathrm{Su}$ & Buckwheat & Sudangrass $^{*}(60 / 50)^{\mathrm{c}}$ & Tilled fallow & Buckwheat \\
\hline & & & $\mathrm{Fa}$ & Oats & \multirow{2}{*}{ Fallow } & \multirow{3}{*}{ Rye* $^{*}$} & \multirow{3}{*}{ Rye \& hairy vetch } \\
\hline & 2009 & 2010 & Wi & Fallow & & & \\
\hline \multirow[t]{2}{*}{2} & & & $\begin{array}{l}\mathrm{Sp} \\
\mathrm{Su}\end{array}$ & \multirow{6}{*}{ Alfalfa* } & \multirow{6}{*}{ Alfalfa/orchardgrass* } & & \\
\hline & & & $\mathrm{Fa}$ & & & \multirow[b]{2}{*}{ Triticale \& hairy vetch } & \multirow[b]{2}{*}{ Rye } \\
\hline \multirow{3}{*}{3} & \multirow[t]{3}{*}{2010} & \multirow[t]{3}{*}{2011} & \multirow{4}{*}{$\begin{array}{l}\mathrm{Wi} \\
\mathrm{Sp} \\
\mathrm{Su} \\
\mathrm{Fa} \\
\mathrm{Wi}\end{array}$} & & & & \\
\hline & & & & & & Corn* $(114 / 123)$ & Corn* $(299 / 258)$ \\
\hline & & & & & & & \\
\hline \multirow[t]{2}{*}{4} & 2011 & 2012 & & & & Fallow & Fallow \\
\hline & & & $\mathrm{Su}$ & Soybean* & Soybean* & Soybean* & Soybean* \\
\hline
\end{tabular}

Adapted from Finney et al. (2015)

a Shaded areas represent rotation phases managed without tillage and un-shaded regions represent crop phases managed with inversion tillage for crop establishment or manure incorporation prior to crop establishment.

${ }^{\mathrm{b}}$ Secondary tillage events include non-inversion soil disturbance events such as field cultivation, tine weeding or discing. 
${ }^{\mathrm{c}}$ Manure application rates $(\mathrm{Mg} / \mathrm{ha})$ are presented in parentheses for Start 1 and Start 2, respectively.

* Crops marked with an asterisk $(*)$ were harvested as cash crops. 
Table 2. Mean crop yields (Mg/ha) for each cropping system and experimental Start. Standard errors of the mean are presented in parentheses.

\begin{tabular}{|c|c|c|c|c|c|c|}
\hline & & & & Rotat & n Year & \\
\hline Start & System & Crop & 1 & 2 & 3 & 4 \\
\hline 1 & 1 & Alfalfa & & $3.6(0.1)$ & $12.4(0.6)$ & \\
\hline & & Soybean & & & & $2.8(0.06)$ \\
\hline & 2 & Sudex & $10.9(1.9)$ & & & \\
\hline & & Alfalfa/Orchardgrass & & $3.8(0.2)$ & $11.0(0.9)$ & \\
\hline & & Soybeans & & & & $2.7(0.1)$ \\
\hline & 3 & Rye & & $10.0(1.4)$ & & \\
\hline & & Corn & & & $6.5(0.9)$ & \\
\hline & & Soybean & & & & $2.3(0.08)$ \\
\hline & 4 & Corn & & & $8.0(0.6)$ & \\
\hline & & Soybean & & & & $2.5(0.07)$ \\
\hline 2 & 1 & Alfalfa & & $4.5(0.3)$ & $9.1(0.3)$ & \\
\hline & & Soybean & & & & $2.8(0.06)$ \\
\hline & 2 & Sudex & $5.6(0.2)$ & & & \\
\hline & & Alfalfa/Orchardgrass & & $4.9(0.1)$ & $10.0(0.6)$ & \\
\hline & & Soybeans & & & & $2.2(0.1)$ \\
\hline & 3 & Rye & & $10.7(0.5)$ & & \\
\hline & & Corn & & & $3.8(0.4)$ & \\
\hline & & Soybean & & & & $2.2(0.1)$ \\
\hline & 4 & Corn & & & $5.0(0.5)$ & \\
\hline & & Soybean & & & & $1.2(0.05)$ \\
\hline
\end{tabular}




\section{Figure legends}

Figure 1. The density of Canada thistle (C. arvense) in four cropping systems that differed in crop rotation and tillage frequency at the initiation (Year 0 ) and in year three of a four-year organic feed and forage cropping systems experiment near Rock Springs, PA. * indicate significant $(P<0.05)$ reductions in $C$. arvense density between Year 0 and Year 3 within a system. Data are least squares means, $\mathrm{n}=8$. Error bars represent standard errors.

Figure 2. Weed biomass (annual and perennial) in four cropping systems that differed in crop rotation and tillage frequency during a soybean uniformity trial at the end of a four-year organic feed and forage cropping systems experiment near Rock Springs, PA. Data are least squares means, $\mathrm{n}=8$. Different letters represent significant differences between systems $(P<0.05)$. Error bars represent standard errors.

Figure 3. Soybean grain yields in a uniformity trial conducted in four cropping systems that differed in crop rotation and tillage frequency near Rock Springs, PA. Data are least squares means, $\mathrm{n}=8$. Different letters represent significant differences between systems $(P<0.05)$. Error bars represent standard errors.

Figure 4. Permanganate oxidizable carbon (POXC) in four cropping systems that differed in crop rotation and tillage frequency sampled in late season (Sept/Oct) of each year in a four-year organic feed and forage cropping systems experiment near Rock Springs, PA. Systems 1 and 3 had a legacy of reduced tillage at the onset of the experiment relative to Systems 2 and 4. Data are least squares means, $\mathrm{n}=8$. Different letters represent significant differences between systems within each year $(P<0.05)$. Error bars represent standard errors.

Figure 5. Nitrogen in aboveground biomass of non-nodulating soybean planted in subplots in four cropping systems that differed in crop rotation and tillage frequency at the end of a fouryear organic feed and forage cropping systems experiment near Rock Springs, PA. Data are least squares means, $\mathrm{n}=8$. Different letters represent significant differences between systems $(P<0.05)$. Error bars represent standard errors.

Figure 6. Least squares mean activity-densities of generalist predatory arthropods (Araneae, Opiliones, Carabidae, Staphylinidae, and Chilopoda) across four cropping systems that differed in crop rotation and tillage frequency over a 4-year organic feed and forage cropping systems experiment near Rock Springs, PA. Different letters represent significant differences between systems within each year $(P<0.05)$. Error bars represent standard errors $(\mathrm{n}=8)$.

Figure 7. Annual cash flows and cumulative net present values (NPV) for four cropping systems that differed in crop rotation and tillage frequency over a four-year organic feed and forage cropping systems experiment, including the establishment year, near Rock Springs, PA. Data are least squares means, $n=6$. Error bars represent standard errors of high, medium and low price scenarios. 


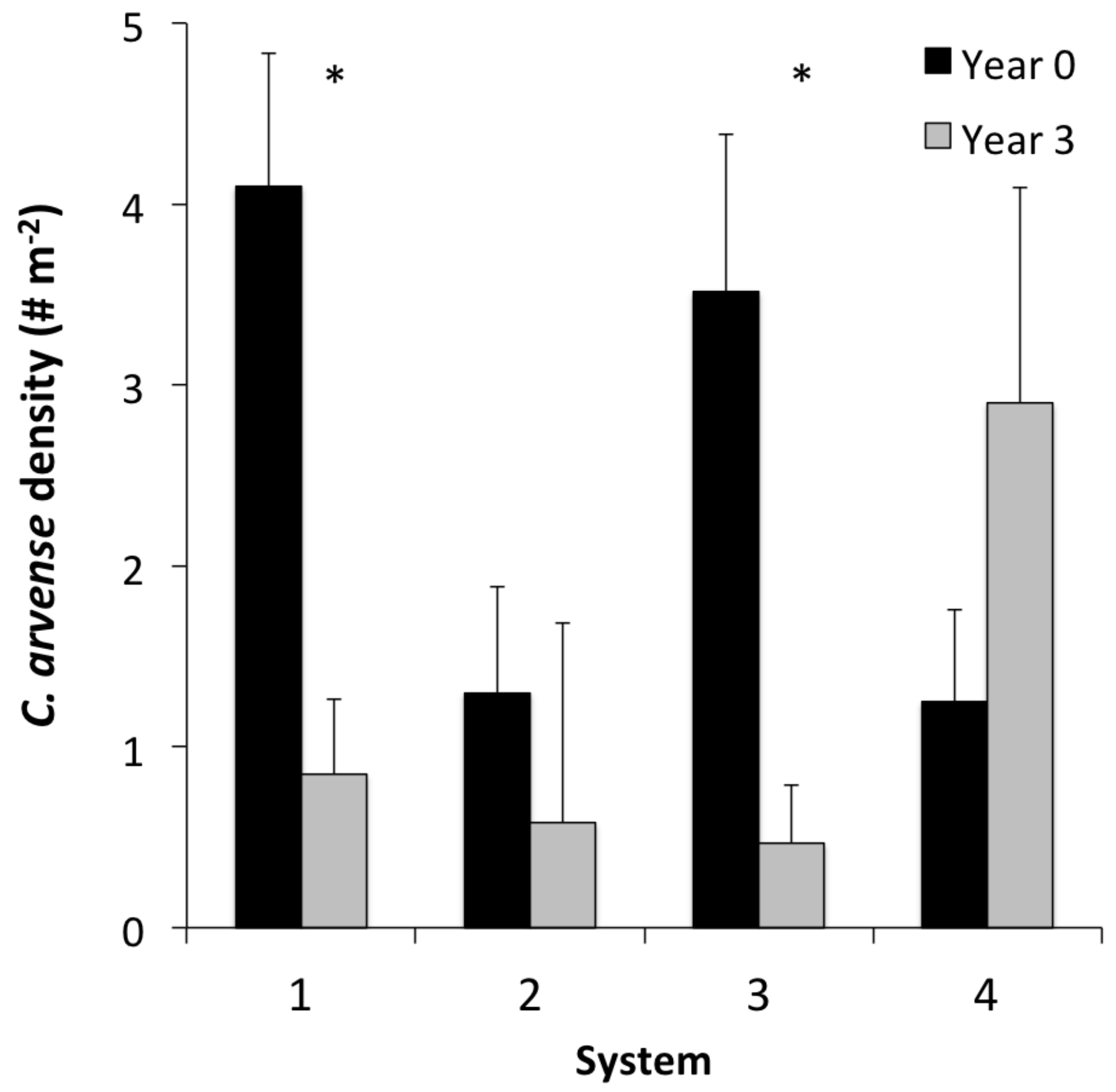




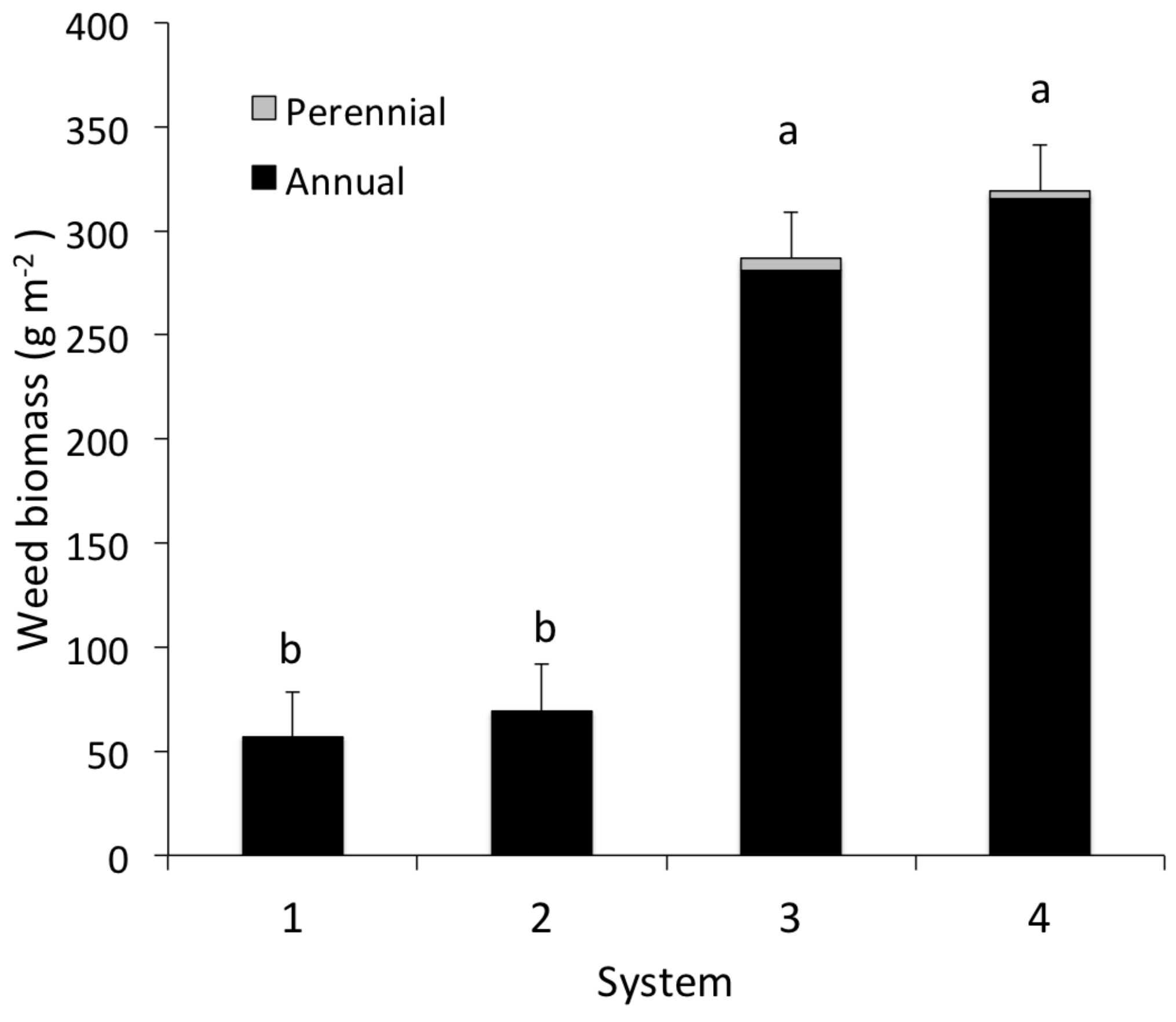




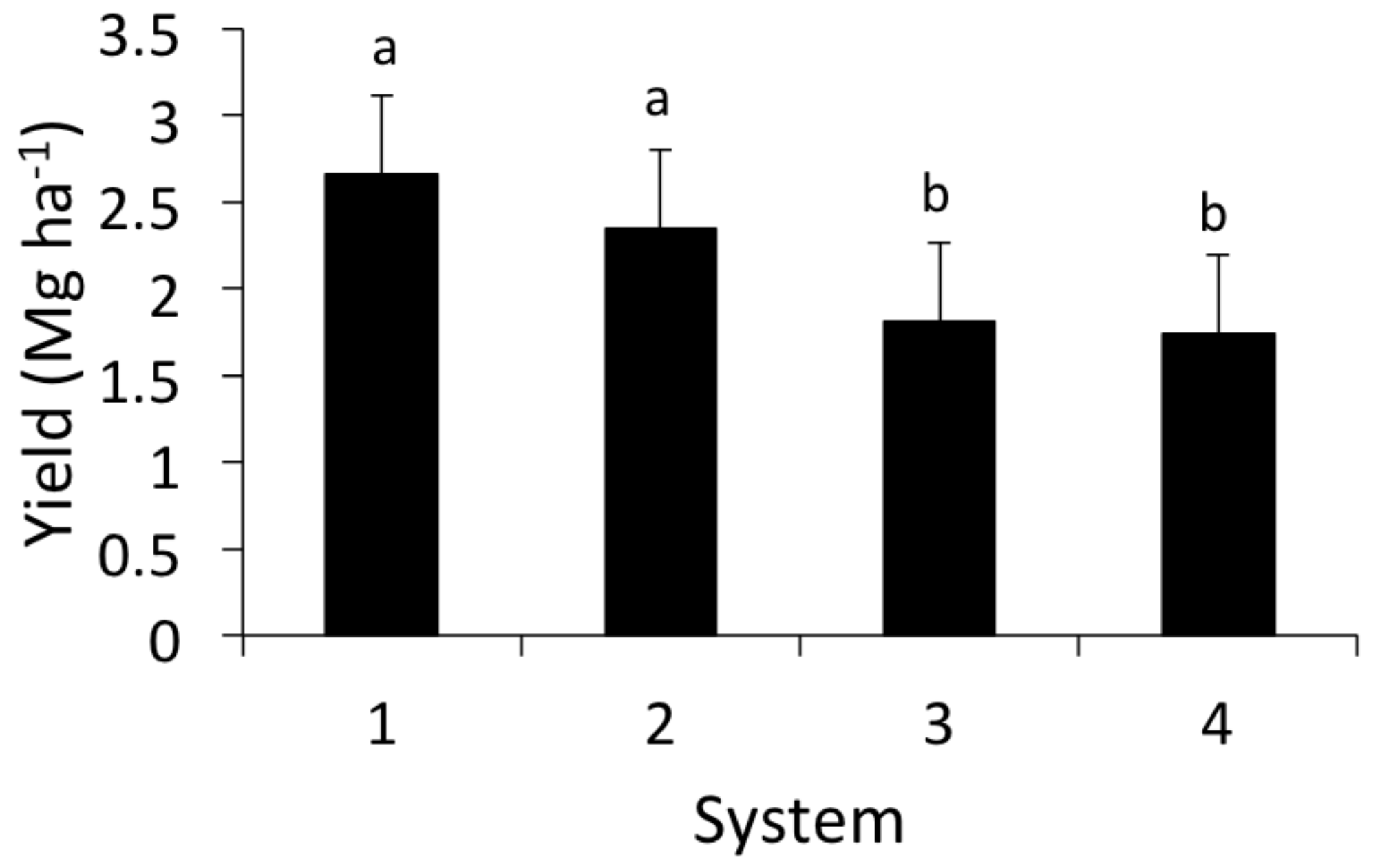




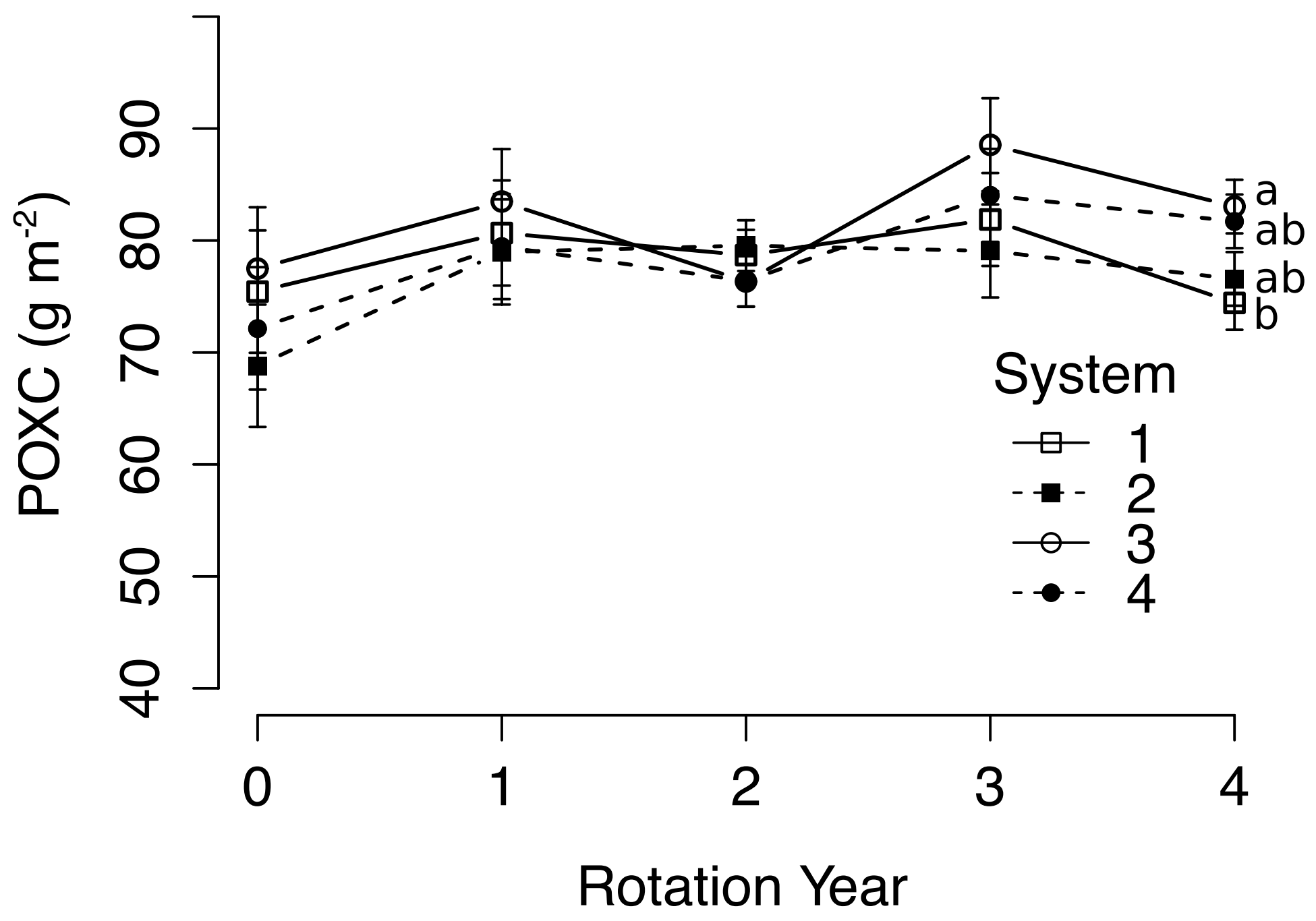




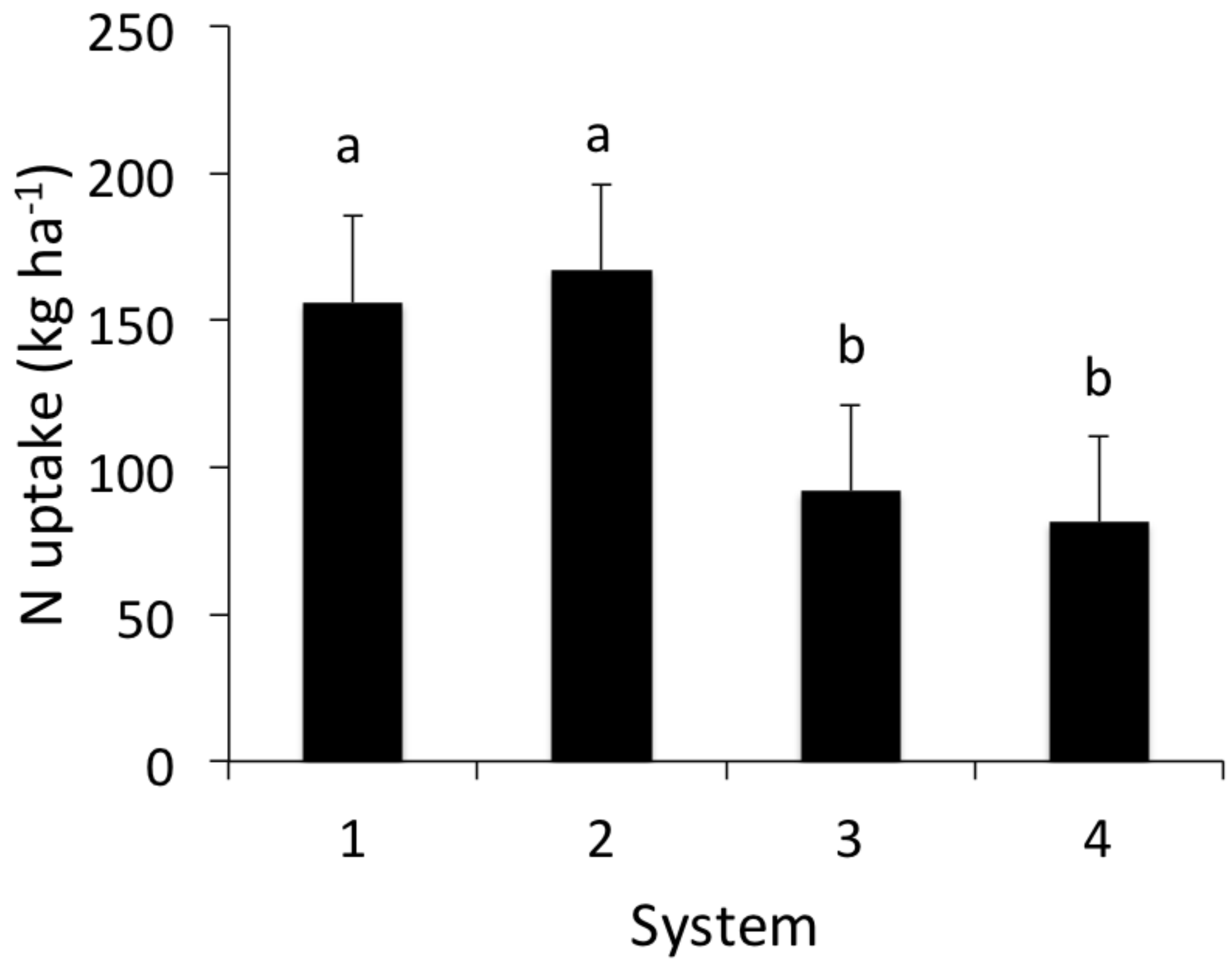




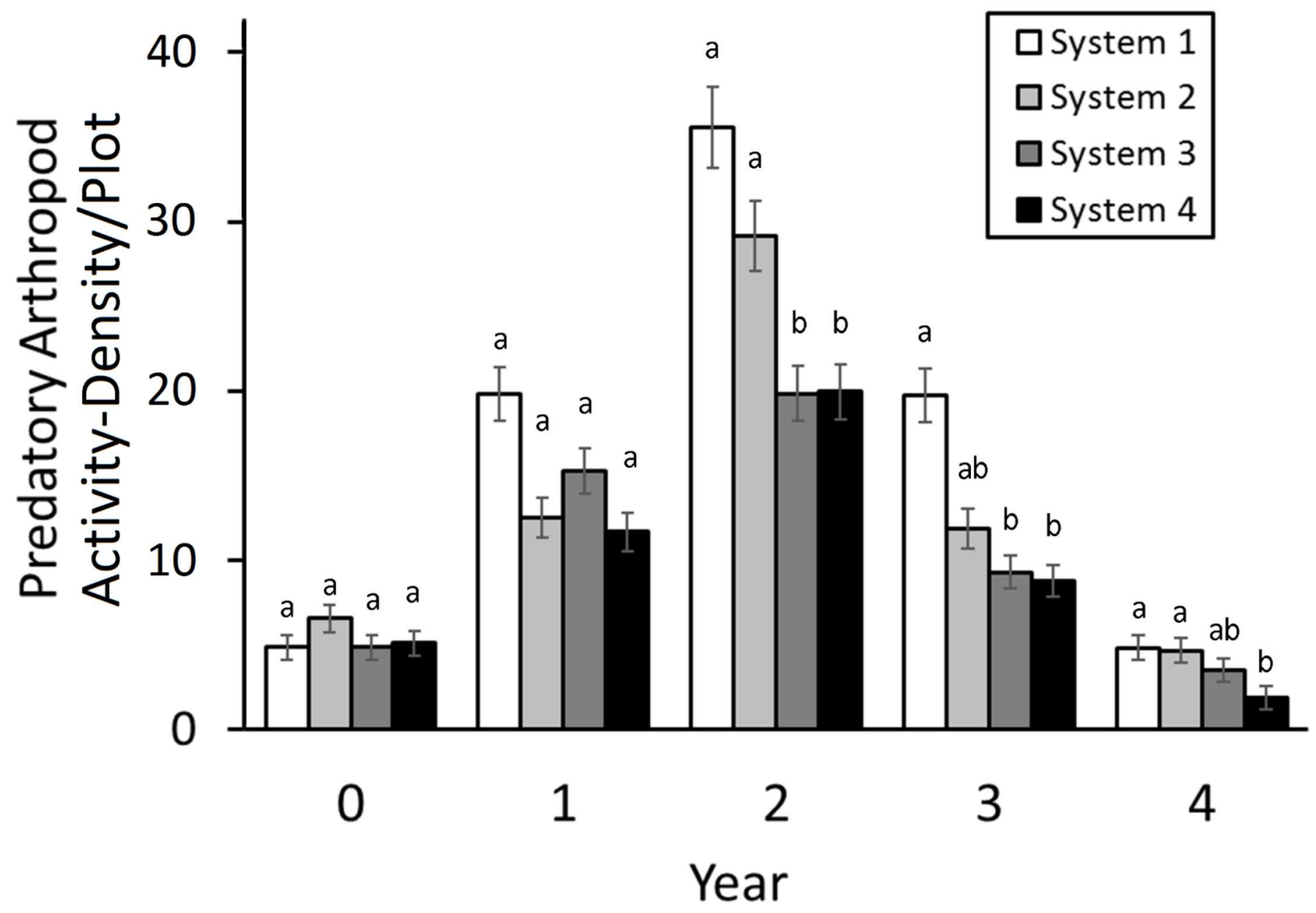




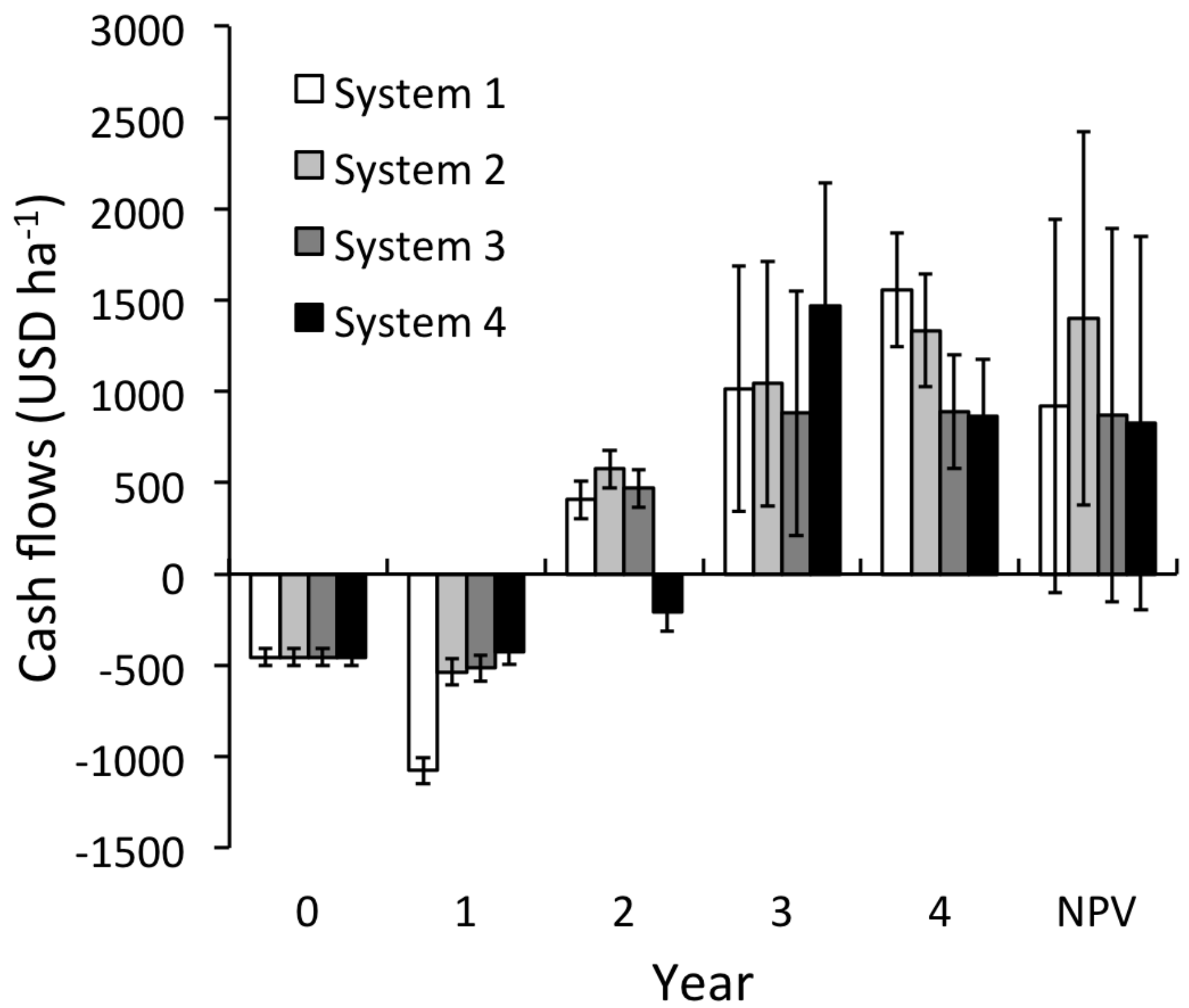

